\title{
Mycotoxin survey of wheat samples graded according to their technological quality
}

\author{
Svetlana Šliková ${ }^{1}$, Soňa Gavurníková1, Martina Mináriková2, Edita Gregová1, Valéria Šudyová1 \\ ${ }^{1}$ National Agriculture and Food Centre, Research Institute of Plant Production, Bratislavská cesta 122, 92168 Pieštany, Slovak \\ Republic \\ ${ }^{2}$ Department of Theoretical Geodesy, Slovak University of Technology, Radlinského 11, 81368 Bratislava, Slovak Republic \\ e-mail: slikova@vurv.sk
}

\begin{abstract}
Wheat grain samples from 108 fields in Slovakia were analysed for their technological quality parameters and deoxynivalenol (DON) content. A total of 206 samples were sorted into those that were suitable $(S ; n=186)$ and those that were unsuitable for human consumption $(U ; n=20)$. The $S$ samples were sorted into grain quality grades $(E-$ elite; A - standard; B - minimum; P - biscuit). The natural occurrences of DON were $72.3 \%$ in the E; $84.9 \%$ in the $A ; 86.1 \%$ in the $B ; 58.1 \%$ in the $P$ and $100.0 \%$ in the $U$ samples. The mean DON content was $0.55 \mathrm{mg} \mathrm{kg}^{-1}$ in the E; $0.47 \mathrm{mg} \mathrm{kg}^{-1}$ in the $A ; 0.67 \mathrm{mg} \mathrm{kg}^{-1}$ in the $B ; 0.36 \mathrm{mg} \mathrm{kg}^{-1}$ in the $P$ and $1.67 \mathrm{mg} \mathrm{kg}^{-1}$ in the $U$ samples. The natural mean DON contamination of the human consumption samples was lower $\left(0.52 \mathrm{mg} \mathrm{kg}^{-1}\right)$ than for the samples that were unsuitable for human consumption $\left(1.67 \mathrm{mg} \mathrm{kg}^{-1}\right)$.
\end{abstract}

Key words: Triticum aestivum L., grains, technological parameters, deoxynivalenol

\section{Introduction}

Wheat was the most important cereal commodity harvested in Europe in 2010 and covered an agricultural area of more than 56 million ha. In 2011 it had reached more than 59 million ha. In Slovakia (located in Central Europe), wheat is grown on $49.9 \%$ of the area where cereals are cultivated. If cereal grains meet certain technological standards, then the grains can be used in food production. If they do not, then they are used in feed. The grain grades are a tool that is used to define the quality of wheat grain used for human consumption. The wheat (Triticum aestivum L.) quality requirements for human consumption purposes are specified in Slovak Technical Standard 46 1100-2:2003-07 (STS 2003). This standard divides wheat into four grain grades. Three of them are for baked goods and one for biscuit goods: E - elite quality, A - standard quality, B - minimum quality requirements for the intervention purchase of wheat and $\mathrm{P}$ - biscuit quality. The technological parameters assessed are: moisture (M), weight volume (Wv), protein content (PC), wet gluten (WG), gluten index (GI); sedimentation index according to Zeleny (SI), and falling number (FN).

Contaminant level is another criterion used to decide whether wheat grains are suitable for food production. Mycotoxins produced by fungi are dangerous contaminants of wheat grain. Grains in spikes can be contaminated during vegetative growth by so-called field mycotoxins produced by Fusarium spp. Many studies have shown that wheat grains attacked by Fusarium spp. can be contaminated by one or more mycotoxins, as well as by so-called masked mycotoxins (i.e. mycotoxin conjugates) (Placinta et al. 1999, Berthiller et al. 2013). Research concerning natural occurrence of mycotoxins in Europe has shown that deoxynivalenol (DON) is one of the most frequently found mycotoxins in foodstuffs (Schollenberger et al. 2005), in feed (Schothorst 2004, Streit et al. 2013), in cereal products and in feed mixtures (Cegielska-Radziejewska et al. 2013) and its occurrence is also considered to be an indicator of the possible presence of other, more toxic, trichothecenes (Jajic et al. 2008). Analyses of cereal products, processed cereal products and wheat-based baby food collected from retailers and farms in Slovakia have confirmed that, of the analyzed Fusarium mycotoxins, DON was the most prevalent in the samples (Belajová et al. 2010). Van der Fels-Klers et al. (2012) suggested that climate changes would increase deoxynivalenol contamination of wheat in northwestern Europe because deoxynivalenol contamination had increased by up to three times in most of the studied regions in northwestern Europe over the past few years.

Arunachalam and Doohan (2013) reported the various toxicological effects of trichothecenes at the cellular and molecular level in humans, animals and plants. The effect of DON alone and in combination with fumonisin B1 was evaluated by Basso et al. (2013) using histological, immunohistochemical and ultrastructural assays of jejunal explants from piglets. They found that DON alone or in combination induces significant damage to intestinal tissue. 
DON and its acetylated derivatives, 3-acetyldeoxynivalenol (3 ADON) and 15-acetyldeoxynivalenol (15 ADON), are mainly produced by Fusarium culmorum and F. graminearum (Bottalico et al. 1998). Chemotype characterisation of F. graminearum and F. culmorum isolates from Central and Southern Europe frequently showed that they were chemotype 15 ADON (Stepień et al. 2008, Talas et al. 2011) and from Northern Europe they were chemotype 3 ADON (Yli-Mattila 2010). The amount of natural contamination by this mycotoxin in wheat samples is influenced by numerous factors (environmental factors, plant growth stage, inoculum dosage, pathogen aggressiveness, chemotype, lodging, tillage system, cultivar resistance and fungicide application), reported Wegulo (2012). A close correlation between Fusarium damage to spikes, Fusarium damage to kernels (FDK), Fusarium protein equivalents (FPE) in kernels and DON content in wheat kernels (Šlikova et al. 2009) was determined in experiments where spikes were artificially infected with Fusarium spp.

It is generally accepted that Fusarium infection leads to grain weight losses and this has an impact on some technological traits. Papoušková et al. (2011) reported that Fusarium damage had a detrimental effect on the technological and baking quality of wheat. Previous studies have analysed flour from wheat grain samples obtained from experiments that had artificially infected grain with Fusarium spp. but the results were not consistent. Prange et al. (2005) reported that high Fusarium infection levels and high DON contents did not necessarily reduce baking quality and this finding was independent of infection time. Several authors have shown that high DON content caused poor flour color, a decline in wet gluten content (Dexter et al. 1996), no reduction in protein content and reductions in Zeleny sedimentation and falling number (Capouchová et al. 2012). Some authors also suggested that there were reductions in dough functionality and loaf volume potential (Nightingale et al. 1999) and an increase in loaf shape deformation (Wang et al. 2005). Gärtner et al. (2008) found that the effects of Fusarium culmorum infection on baking quality parameters, water absorption, dough softening and dough resistance differed between susceptible varieties and resistant varieties.

The aims of this study were (1) to monitor the technological quality of wheat samples collected from maize production regions; (2) to determine the potential of natural contamination of wheat samples suitable for human consumption by mycotoxin DON content; (3) to compare the sample contamination levels in the different wheat quality grades and (4) to investigate whether samples containing excessive amounts of DON occur in other wheat samples that were graded as being suitable for human consumption.

\section{Material and Methods}

\section{Samples}

Mature wheat grains were collected during the 2010 and 2011 growing seasons so that their technological parameters and DON content could be measured. A total of 206 samples were provided directly by growers. Each sample (2000 g) was collected from fields in Slovakia (Fig. 1 and Fig. 2) that were located in a maize producing region where the elevation above sea level is $112-200$ meters; average annual temperature is $9-10{ }^{\circ} \mathrm{C}$ and annual rainfall is above $600 \mathrm{~mm}$. The soils in the region are black and, in particular, brown soils. The growers used perennial fodder crops, legumes, mixtures of legumes and cereals, rapeseed and maize for silage as preceding crops. The several individual samples were taken from one collection place (from particular variety). The total average sample with the weight of $2000 \mathrm{~g}$ was divided into 2 parts (1000 g to determine technological parameters and $1000 \mathrm{~g}$ to determine DON content). After grinding the full lot sample, a subsample was taken for analysis.

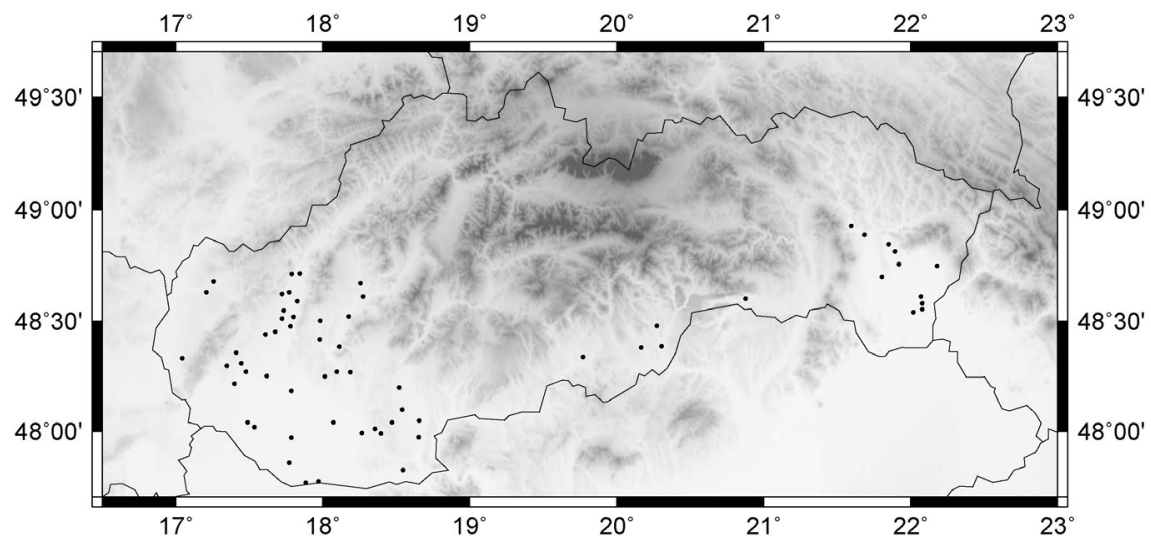

Fig. 1. Field locations in the Slovak Republic from which wheat samples were collected in $2010(n=62)$. 


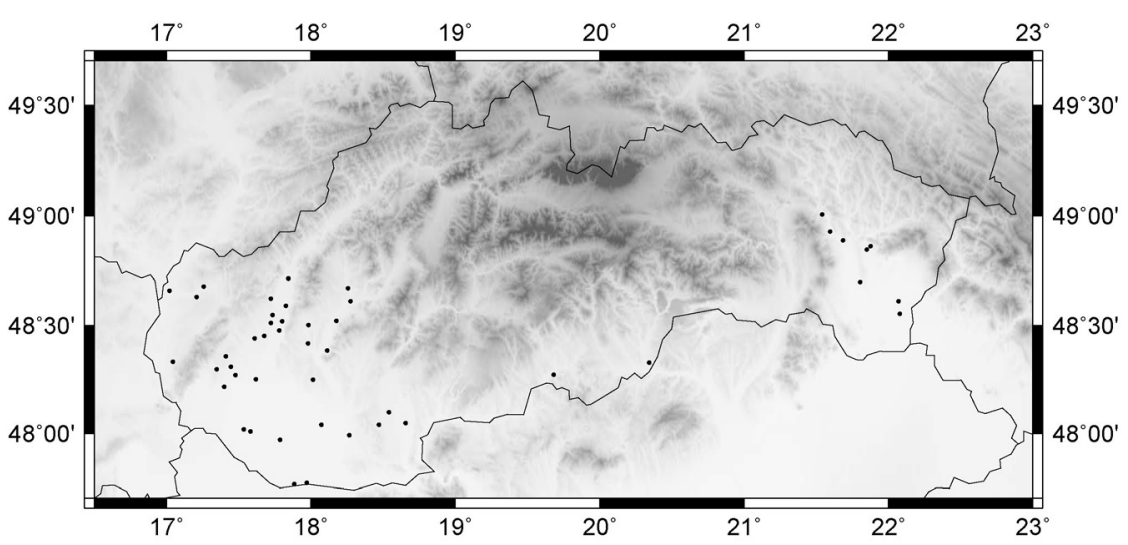

Fig. 2. Field locations in the Slovak Republic from which wheat samples were collected in $2011(n=46)$.

\section{Technological parameter analyses}

The weight volume was determined according to EN ISO 7971-3 (GAC ${ }^{\circledR} 500$ XT, DICKEY-John Europe S.A.S, France). The nitrogen content was determined according to Dumas (TruMac N, LECO Corporation, St. Joseph, MI). A conversion factor of 5.7 was used to calculate the protein content from the nitrogen content (AACC 46-30.01). The wet gluten content and the gluten index were determined according to ICC Standard No.155 (Glutomatic 2200, Perten Instrumenst, Sweden). The gluten index (GI) is a method of analysing wheat protein that provides a simultaneous determination of gluten quality and quantity. The GI value expresses a weight percentage of the wet gluten remaining on a sieve after automatic washing in salt solution and centrifugation (Centrifuge 2015, Perten Instrumenst, Sweden). GI allows a reliable prediction of bread making quality by means of the Zeleny sedimentation index, which was determined according to ISO 5529 (Shaker Brabender, Germany). The falling number was determined according to ISO 3093 (Falling Number 1800, Perten Instruments, Sweden). All parameters were analysed in duplicate.

Slovak technical standards (STS) 46 1100-2 for cereals destined for human consumption are described in Table 1.

Table 1. Grades of wheat quality and minimum values of parameters according Slovak Technical Standard (STN 46 1100-2, 2003).

\begin{tabular}{|c|c|c|c|c|}
\hline Parameter & \multicolumn{4}{|c|}{ Grade } \\
\hline Moisture ( \%) & 14 & 14 & 14 & 14 \\
\hline 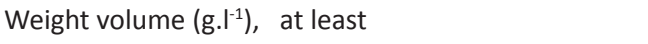 & 780 & 760 & 730 & 750 \\
\hline Nitrogen content $(\mathrm{N} \times 5,70)$ in dry mass $(\%)$, at least & 12.5 & 11.5 & 10.5 & 9.5 \\
\hline Falling number in groat of $7 \mathrm{~g}(\mathrm{~s})$, at least & 220 & 220 & 220 & 160 \\
\hline Sedimentation index according Zeleny $(\mathrm{ml})$, at least & 30 & 25 & 22 & - \\
\hline \multicolumn{5}{|l|}{ Recommended quality trait } \\
\hline Wet gluten content in dry mass (test $\mathrm{G}_{0}$ ) $(\%)$, at least & 27 & 25 & 23 & 20 \\
\hline
\end{tabular}

$\mathrm{E}$ - elite quality, A - standard quality, B - minimum quality requirements for intervention purchase of wheat, $\mathrm{P}$ - biscuit quality

\section{Deoxynivalenol}

A commercial ELISA kit was used to determine the DON concentration in the wheat samples (Ridascreen Fast DON, RBiopharm, Darmstadt, Germany) with limit of detection $<0.2 \mathrm{mg} . \mathrm{kg}^{-1}(\mathrm{ppm})$ and limit of quantification $0.2 \mathrm{mg} . \mathrm{kg}^{-1}$ (ppm). The grain samples were ground (Ultra Centrifugal Mill, type ZM 100, Retsch, Haan, Germany) with sieve size $1.00 \mathrm{~mm}$. Then $100 \mathrm{ml}$ of distilled water was added to $5 \mathrm{~g}$ of each sample and the mixture filtered. The filtrate, in aliquots of $50 \mu \mathrm{l}$, was used for analysis. The absorbencies of the wells were determined photometrically at 450 $\mathrm{nm}$ (MRX II, Dynex Technologies, Chantilly, Virginia, USA) and the DON concentrations were calculated in $\mathrm{mg} \bullet \mathrm{kg}^{-1}$ by Revelation Version 4.25 (Dynex Technologies). Statistical analysis was performed using SPSS software 11.5 (SPSS, Chicago, Illinois, USA) and the statistical significance levels were set at $95 \%(p<0.05)$ and $99 \%(p<0.01)$. 


\section{Results and discussion \\ Technological parameter analyses of the wheat samples}

Table 2 shows the results from the technological parameter analyses for all the wheat samples $(n=206)$. ANOVA analysis of M, Wv, PC, WG, GI and FN showed that there were significant differences between the years, except for Zeleny sedimentation index (ZS) where there was no significant difference, which showed that this parameter was the least affected by the weather (Table 2). The average values for the technological parameters showed that all the samples reached grade E according to the STS criteria (2003, Table 1) in 2010, but in 2011 the PC parameter only reached grade $A$ (Table 2). The quality of the analyzed samples was higher in 2010 than in 2011. Around $9.7 \%$ of the samples did not meet the $\mathrm{S}$ grade required for food consumption (2003) and were classified as unsuitable for food consumption (U). All the other samples were classified as suitable for food consumption (S) (Table 3). In 2010 and 2011, $10.7 \%$ and $8.7 \%$, respectively, of the grain samples did not meet the STS criteria (2003).

Table 2. Technological parameter values and grades for the wheat samples collected in 2010 and 2011.

\begin{tabular}{|c|c|c|c|c|c|c|c|c|c|}
\hline Harvest & Analysed & & $\begin{array}{l}\mathrm{M} \\
\% \\
\end{array}$ & $\begin{array}{l}\text { Wv } \\
\mathrm{g} \mathrm{l}^{-1}\end{array}$ & $\begin{array}{c}\text { PC } \\
\% \\
\end{array}$ & $\begin{array}{c}\text { WG } \\
\%\end{array}$ & GI & $\begin{array}{c}\mathrm{FN} \\
\mathrm{s}\end{array}$ & $\begin{array}{l}\mathrm{ZS} \\
\mathrm{ml}\end{array}$ \\
\hline \multirow[t]{5}{*}{2010} & 103 & Mean & 13.5 & 785.8 & 13.1 & 29.2 & 73.3 & 332.7 & 39.3 \\
\hline & & Median & 13.5 & 786.0 & 13.1 & 29.7 & 77.0 & 346.0 & 40.0 \\
\hline & & Min. & 11.8 & 713.0 & 10.3 & 18.6 & 15.0 & 185.0 & 21.0 \\
\hline & & Max. & 14.7 & 869.0 & 16.3 & 39.4 & 98.0 & 409.0 & 64.0 \\
\hline & & Grade & $\mathrm{E}$ & $\mathrm{E}$ & $\mathrm{E}$ & $E$ & - & $E$ & $\mathrm{E}$ \\
\hline \multirow[t]{5}{*}{2011} & 103 & Mean & 13.0 & 803.9 & 12.0 & 27.3 & 80.2 & 269.7 & 39.6 \\
\hline & & Median & 13.0 & 811.0 & 12.0 & 27.3 & 89.0 & 279.0 & 40.0 \\
\hline & & Min. & 11.2 & 698.0 & 8.9 & 12.8 & 8.0 & 91.0 & 16.0 \\
\hline & & Max. & 15.1 & 850.0 & 14.8 & 40.1 & 99.0 & 400.0 & 61.0 \\
\hline & & Grade & $\mathrm{E}$ & $\mathrm{E}$ & A & $E$ & - & $E$ & $\mathrm{E}$ \\
\hline \multirow[t]{4}{*}{ Total } & 206 & Mean & 13.3 & 794.9 & 15.6 & 28.2 & 76.8 & 301.2 & 39.5 \\
\hline & & Median & 13.3 & 797.5 & 12.5 & 28.5 & 84.0 & 307.5 & 40.0 \\
\hline & & $\mathrm{F}$ & 34.27 & 19.84 & 40.63 & 8.45 & 6.26 & 60.71 & 0.07 \\
\hline & & $p$ & $0.00 *$ & $0.00 *$ & $0.00 *$ & $0.00 *$ & $0.01^{*}$ & $0.00 *$ & 0.79 \\
\hline
\end{tabular}

$\mathrm{M}$ - moisture, $\mathrm{Wv}$ - weight volume, $\mathrm{PC}$ - protein content, WG - wet gluten content, GI - gluten index, FN - falling number, ZS - Zeleny sedimentation index, E - elite quality, A - standard quality, F-value, $p$ - value, * significant difference based on Tukey at $p<0.01$

Table 3. The mean technological parameter values of samples that were suitable and unsuitable for human consumption according to the STS (2003).

\begin{tabular}{|c|c|c|c|c|c|c|}
\hline \multirow{4}{*}{ Parameter } & \multicolumn{4}{|c|}{ Harvest } & \multicolumn{2}{|c|}{ Total } \\
\hline & \multicolumn{2}{|c|}{2010} & \multicolumn{2}{|c|}{2011} & & \\
\hline & \multicolumn{2}{|c|}{ Sample (N) } & \multicolumn{2}{|c|}{ Sample (N) } & \multicolumn{2}{|c|}{ Sample (N) } \\
\hline & S (94) & U (9) & $S(92)$ & $U(11)$ & S (186) & $U(20)$ \\
\hline$M$ & 13.50 & 13.54 & 12.98 & 13.39 & 13.24 & 13.46 \\
\hline Wv & 789.68 & 745.44 & 808.61 & 764.91 & 799.04 & 756.15 \\
\hline PC & 13.20 & 12.06 & 12.14 & 10.97 & 12.68 & 11.46 \\
\hline WG & 29.58 & 24.72 & 28.02 & 21.19 & 28.81 & 22.78 \\
\hline GI & 73.27 & 73.11 & 79.60 & 85.64 & 76.40 & 80.00 \\
\hline FN & 332.88 & 330.22 & 280.02 & 183.73 & 306.74 & 249.65 \\
\hline ZS & 39.91 & 33.22 & 40.46 & 32.73 & 40.18 & 32.95 \\
\hline
\end{tabular}

(N) - Number, S - suitable for human consumption, $\mathrm{U}$ - unsuitable for human consumption, $\mathrm{M}$ - moisture, $\mathrm{Wv}$ - weight volume, PC - protein content, WG - wet gluten content, GI - gluten index, FN - falling number, ZS - Zeleny sedimentation index 


\section{DON content in wheat samples classified according to the STS (2003)}

The number of samples that were positive for DON content in 2010 and 2011 are summarized in Table 4 . The mean grain contamination by DON for all samples was significantly different between the 2 years $(p<0.000)$. On average, $80.1 \%$ of the analysed samples was contaminated. The percentage contamination was higher in 2010 (93.2 $\%)$ than in 2011 (66.9\%). Differences between the mean sample contaminations show that the samples taken in 2010 were 3.3 times more contaminated than the samples taken in 2011 and the median value was also higher in 2010. Exactly $77.9 \%$ of the $S$ samples was contaminated by DON and the number of contaminated samples was $29.6 \%$ higher in 2010 than in 2011. In the U group, all samples were positive for DON content and their total average contamination level was $68.9 \%$ higher than in the S samples. The DON content in the U samples in 2010 and 2011 was four times higher and 1.9 times higher, respectively, than it was in the S samples. The higher DON content in 2010 compared to 2011 is probably related to precipitation, which was higher in May (168 mm) and June $(127 \mathrm{~mm}$ ) in 2010 than in 2011 (May = $45 \mathrm{~mm}$; June $=84 \mathrm{~mm}$ ). Furthermore, average temperatures were lower in 2010 ( May $=15.2^{\circ} \mathrm{C}$; June $=19.2^{\circ} \mathrm{C}$ ) than in 2011 (May $=16.1^{\circ} \mathrm{C}$; June $\left.=19.9^{\circ} \mathrm{C}\right)$. These data were accessed from meteorological weather stations that were located near the collection sites in Slovakia and showed that the average precipitation was greater in 2010 (May and June) when wheat was at the flowering and ripening stages, respectively. These results correspond with previously published data where there was a positive relationship between rainfall and DON content in wheat. The previous data were obtained from samples taken from wheat cultivated between 2004 and 2006 in Slovakia (Šliková et al. 2008). Weather conditions during the flowering and ripening stages of wheat were critical for FHB development. A previous study showed that high temperatures in central Poland during July and August in 2009, accompanied by high rainfall in July were responsible for the high DON levels in wheat (Wiśniewska et al. 2014). Chandelier and Nimal (2011) found a strong correlation between mean annual DON content and number of days with mean relative humidity above $80 \%$ over a period starting 7 days before the mean flowering date and ending on the 16th day of flowering. The wet weather before harvest seems to be particularly bad for cereal contamination of mycotoxins as well as of DON (Bernhoft et al. 2013).

A negative relationship was observed between some of the evaluated technological parameters (WV, GI and ZS) and DON content (Table 5). These results agree with numerous scientific studies on the effects of fusarium infection on the technological quality traits of wheat. Siuda et al. (2010) reported that fusariosis had an impact on the grain weight of infested grain and Dexter et al. (1996) also observed that grain weight decreased as the number of fusarium damaged grains in samples increased. It has been found that the fungal protease produced by Fusarium culmorum may damage storage proteins (Wang et al. 2005) and this can influence the Gl value. Dexter et al. (1996) reported a decrease in glutenins in wheat infected by F. graminearum, but no qualitative differences in gliadins were observed. According to Prange et al. (2005), the gluten network was not attacked by Fusarium spp. and only small changes in the glutenin levels were observed. Many studies have shown that there is a reduction in ZS after wheat had been artificially infected with Fusarium (Gärtner et al. 2008, Papoušková et al. 2011). There was also a reduction in FN (Papoušková et al. 2011). Wang et al. (2005) found that there was negative correlation between Fusarium protein equivalent and the sedimentation value of wheat flour after Fusarium culmorum infection. According to Gärtner et al. (2008), this indicates that although the total amount of protein remains quite stable, the infection may alter its quality.

Table 4. The occurrence of deoxynivalenol in wheat samples according to years.

\begin{tabular}{llccccc}
\hline Sample & Harvest & $\begin{array}{c}\text { No. of samples } \\
\text { Analysed/ } \\
\text { positives }^{1}\end{array}$ & Average & Min. & Max. & Median \\
\hline \multirow{3}{*}{ S } & 2010 & $94 / 87$ & 0.76 & 0.20 & 2.94 & 0.49 \\
& 2011 & $92 / 58$ & 0.27 & 0.20 & 2.12 & 0.20 \\
& Total & $186 / 145$ & 0.52 & 0.20 & 2.94 & 0.20 \\
\multirow{4}{*}{ U } & 2010 & $9 / 9$ & 3.07 & 0.27 & 7.88 & 1.89 \\
& 2011 & $11 / 11$ & 0.53 & 0.22 & 1.75 & 0.33 \\
& Total & $20 / 20$ & 1.67 & 0.22 & 7.88 & 0.40 \\
& 2010 & $103 / 96$ & $0.96^{*}$ & 0.20 & 7.88 & 0.51 \\
& 2011 & $103 / 69$ & 0.29 & 0.20 & 2.12 & 0.20 \\
& Total & $206 / 165$ & 0.63 & 0.20 & 7.88 & 0.25 \\
\hline
\end{tabular}

$\mathrm{S}$ - suitable for human consumption, $\mathrm{U}$ - unsuitable for human consumption, DON - deoxynivalenol,

* significant difference based on Tukey test at $p<0.01$

${ }^{1}$ Positive samples: mycotoxin concentration above detection limit $>0.2 \mathrm{mg} \mathrm{kg}^{-1}$, 
Table 5. Correlations among the technological parameters and deoxynivalenol content.

\begin{tabular}{lccccccc}
\hline Parameter & $M$ & Wv & PC & WG & GI & FN & ZS \\
\hline DON & 0.097 & $-0.316^{* *}$ & 0.079 & -0.008 & $-0.169^{*}$ & 0.072 & $-0.165^{*}$ \\
\hline
\end{tabular}

$\mathrm{M}$ - moisture (\%), $\mathrm{Wv}$ - weight volume $\left(\mathrm{g}^{-1}\right), \mathrm{PC}$ - protein content (\%), WG - wet gluten content ( \%),

$\mathrm{Gl}$ - gluten index, $\mathrm{FN}$ - falling number (s), ZS - Zeleny sedimentation index (ml),

DON - deoxynivalenol $\left(\mathrm{mg} \mathrm{kg}^{-1}\right)$

**Correlation is significant at the 0.01 level, *Correlation is significant at the 0.05 level

\section{DON occurrence in different grades of S wheat samples}

Table 6 shows that the total occurrence of $S$ samples contaminated by DON in grades $E, A, B$ and $P$ ranged from $58.1 \%$ to $86.1 \%$ and the lowest percentage occurrence of positive samples was found in the $P$ grade (wheat suitable for bread-making). Differences between 2010 and 2011 in the occurrence of positive samples were the highest in grades $\mathrm{E}(33.3 \%)$ and $\mathrm{P}(32.4 \%)$. The total average contamination of the $\mathrm{S}$ samples was the highest for the $B$ grade. In 2010, the mean contamination of the $S$ sample quality grades ranged from $0.54 \mathrm{mg} \mathrm{kg}^{-1}$ to $1.04 \mathrm{mg} \mathrm{kg}$ ${ }^{1}$. However, in 2011 the difference between the grades was only $0.05 \mathrm{mg} \mathrm{kg}^{-1}$. The median levels were the same for both years in the P grade samples. However, they were higher in the other grades in 2010.

\section{Excessive DON content in wheat samples}

Samples with excessive DON content were found. The limit for DON content imposed by the European Union (1.25 $\mathrm{mg} \mathrm{kg}^{-1}$ ) was exceeded in $11.7 \%$ (24 samples) of the samples analyzed (Table 6). The limit is the current maximum level allowed in the European Union for unprocessed cereals other than durum wheat, oats and maize (European Commission 2006). Samples with excessive DON content occur when favorable climatic conditions are created for the development of FHB disease at the same time as other factors that support the development of the disease are present, such as ongoing precipitation during harvest, an unsuitable preceding crop (mainly maize) or no fungicides were applied (Koch et al. 2006). Edwards (2009) states that the percentage of samples above these limits will fluctuate in the coming years.

Table 6. The occurrence of, and deoxynivalenol content in, wheat classified according to the STS (2003).

\begin{tabular}{|c|c|c|c|c|c|c|c|}
\hline \multirow[b]{2}{*}{ Harvest } & \multirow[b]{2}{*}{ G } & \multicolumn{6}{|c|}{ DON mg kg-1 } \\
\hline & & Grade & Analysed/P $-(\%)$ & Average & Max. & Median & $P^{2}-(\%)$ \\
\hline \multirow{5}{*}{2010} & \multirow{4}{*}{$\mathrm{S}$} & $E$ & $37 / 34-(91.9)$ & 0.74 & 2.94 & 0.50 & $4-(10.8)$ \\
\hline & & $A$ & $28 / 27-(96.4)$ & 0.67 & 2.20 & 0.52 & $3-(10.7)$ \\
\hline & & $\mathrm{B}$ & $19 / 18-(94.7)$ & 1.04 & 2.80 & 0.58 & $6-(31.5)$ \\
\hline & & $\mathrm{P}$ & $10 / 8-(80.0)$ & 0.54 & 2.01 & 0.20 & $2-(20.0)$ \\
\hline & $U$ & & $9 / 9-(100.0)$ & 3.07 & 7.88 & 1.89 & $5-(55.5)$ \\
\hline \multirow{5}{*}{2011} & \multirow{4}{*}{$\mathrm{S}$} & $E$ & $29 / 17-(58.6)$ & 0.29 & 2.12 & 0.20 & $1-(3.4)$ \\
\hline & & $A$ & $25 / 18-(72.0)$ & 0.24 & 1.24 & 0.20 & $1-(4.0)$ \\
\hline & & B & $17 / 13-(76.5)$ & 0.25 & 0.61 & 0.20 & $0-(0.0)$ \\
\hline & & $\mathrm{P}$ & $21 / 10-(47.6)$ & 0.27 & 0.75 & 0.20 & $0-(0.0)$ \\
\hline & $U$ & & $11 / 11-(100.0)$ & 0.53 & 1.75 & 0.33 & $2-(18.2)$ \\
\hline \multirow{5}{*}{ Total } & \multirow{4}{*}{$\mathrm{S}$} & $E$ & $66 / 51-(72.3)$ & 0.55 & 2.94 & 0.33 & $5-(7.5)$ \\
\hline & & $A$ & $53 / 45-(84.9)$ & 0.47 & 2.20 & 0.20 & $4-(7.5)$ \\
\hline & & $\mathrm{B}$ & $36 / 31-(86.1)$ & 0.67 & 2.80 & 0.26 & $6-(16.6)$ \\
\hline & & $\mathrm{P}$ & $31 / 18-(58.1)$ & 0.36 & 2.01 & 0.20 & $2-(6.5)$ \\
\hline & U & & $20 / 20-(100)$ & 1.67 & 7.88 & 0.37 & $7-(35.0)$ \\
\hline
\end{tabular}

G - Group, ${ }^{1}$ Positive samples - mycotoxin concentration above detection limit $>0.2 \mathrm{mg} \mathrm{kg}{ }^{-1}$, ${ }^{2}$ Positive samples mycotoxin concentration above detection limit $>1.25 \mathrm{mg} \mathrm{kg}^{-1}, \mathrm{~S}$ - suitable for human consumption, $\mathrm{U}-$ unsuitable for human consumption, E- elite quality, A - standard quality, B - minimum quality requirements for intervention purchase of wheat, $\mathrm{P}-$ biscuits quality 
The occurrence of samples with excessive DON content in Great Britain between 2001 and 2005 ranged from 0.4 \% to $11.3 \%$ (Edwards 2009). In Slovakia, between 2004 and 2008, the occurrence of excessive DON levels ranged from $0.0 \%$ to $4.3 \%$ in samples collected from the maize production region (Šliková et al. 2008). In this study, the excessive sample occurrence differed between the years. In 2011, the allowed limit was exceeded in $3.7 \%$ of the samples and in 2010 it was $19.4 \%$. Table 6 shows that excessive samples occurred among the $\mathrm{S}$ and $\mathrm{U}$ samples and among the different $S$ sample quality grades. We found out that wheat samples with good technological parameters can contain excessive amounts of DON. Our results were also supported by Polišenská (2011), who found a wheat sample in the Czech Republic in 2010 that contained an excessive DON content (1.559 mg kg-1), even though it had very good technological parameters ( $\mathrm{Wv}=796 \mathrm{gl}^{-1}, \mathrm{FN}=345 \mathrm{~s}, \mathrm{ZS}=52 \mathrm{ml}$ and N=13.5 \%). Prange et al. (2005) came to the conclusion that high Fusarium infection levels, accompanied by high DON contents, did not necessarily reduce baking quality. According to our results, the highest percentage of samples exceeding the permitted DON limit occurred in the $U$ samples and the highest DON levels were also found in these samples. In 2010, when samples were on average 3.3 times more contaminated than in 2011, half of the U samples contained excessive amounts of DON (Table 6).

\section{Conclusion}

These results show that there were significant differences in the technological quality of wheat grain and natural contamination by DON between 2010 and 2011. The occurrence and the level of DON contamination in samples suitable for human consumption were lower than in unsuitable samples. There were no differences in natural contamination of samples by DON among samples classified into grades according to their technological quality parameters. This research on the occurrence of the mycotoxin has also shown that samples with high technological qualities can contain dangerous amounts of DON. This inevitably implies that DON levels and incidence need to be controlled in wheat intended for human consumption and for feed.

\section{Acknowledgements}

This work was supported by OP Research and Development: Development of new types of genetically modified plants with farm traits (ITMS 26220220027), by the European Regional Development Fund and by the Science and Research Support Agency (No. APVV-0398-12) of the Slovak Republic.

\section{References}

Arunachalam, Ch. \& Doohan, F. M. 2013. Trichothecene toxicity in eukaryotes: Cellular and molecular mechanisms in plants and animals. Toxicology letters 217: 149-158.

Basso, K., Gomes, F. \& Bracarense, A. P. L. 2013. Deoxynivanelol and Fumonisin, Alone or in Combination, Induce Changes on Intestinal Junction Complexes and in E-Cadherin Expression. Toxins 5: 2341-2352.

Belajová, E. \& Rauová, D. 2010. Single laboratory-validated HPLC methods for determination of ochratoxin A, fumonisin B1 and B2, zearalenone and deoxynivalenol in cereals and cereal-based foods. Journal of Food and Nutrition Research 49: 57-68.

Bernhoft, A., Torp, M., Clasen P. E., Løes, A. K. \& Kristoffersen, A. B. 2013. Influence of agronomic and climatic factors on Fusarium infestation and mycotoxin contamination of cereals in Norway. Food Additives \& Contaminants: Part A 29: 1129-1140.

Berthiller, F., Crews, C., Dall'Asta, Ch., Saeger, S., Haesaert, G., Karlovsky, P., Oswald, I. P., Seefelder, W., Speijers, G. \& Stroka, J. 2013. Masked mycotoxins: A review. Molecular Nutrition \& Food Research 57: 165-186.

Bottalico, A. 1998. Fusarium Diseases of Cereals: Species complex and related mycotoxin profiles in Europe. Journal of Plant Pathology 80: 85-103.

Capouchová, I., Papoušková, L., Kostelanská, M., Prokinová, E., Škeříková, A., Hajšlová, J., Konvalina, P. \& Faměra, O. 2012. Effect of different intensities of Fusarium infestation on grain yield, Deoxynivalenol content and baking quality of winter wheat. Romanian Agricultural Research 29: 297-306.

Cegielska-Radziejewska, R., Stuper, K. \& Szablewski, T. 2013. Microflora and mycotoxin contamination in poultry feed mixtures from western Poland. Annals of Agricultural and Environmental Medicine 20: 30-35.

Chandelier, A. \& Nimal, C. 2011. Fusarium species and DON contamination associated with head blight in winter wheat over a 7-year period (2003-2009) in Belgium. European Journal of Plant Pathology 130: 403-414.

Dexter, J. E., Clear, R. M. \& Preston, K. R. 1996. Fusarium head blight: Effect on the milling and baking of some Canadian wheats. Cereal Chemistry 73: 695-701.

Edwards, S. G. 2009. Fusarium mycotoxin content of UK organic and conventional wheat. Food Additives \& Contaminants: Part A 26: 496-506. 
European Commission Regulation. 2006. Commission Regulation (EC) No 1881/2006 of 19 December 2006 amending Regulation (EC) setting maximum levels for certain contaminants in foodstuffs. Official Journal of the European Union L 364: 5-24.

Gärtner, B. H., Munich, M., Kleijer, G. \& Mascher, F. 2008. Characterisation of kernel resistance against Fusarium infection in spring wheat by baking quality and mycotoxin assessments. European Journal of Plant Pathology 120: 61-68.

Jajic, I., Juric, V., Glamocic, D. \& Abramovic, B. 2008. Occurrence of deoxynivalenol in maize and wheat in Serbia. International Journal of Molecular Sciences 9: 2114-2126.

Koch, H. J., Pringas, C. \& Maerlaender, B. 2006. Evaluation of environmental and management effects on Fusarium head blight infection and deoxynivalenol concentration in the grain of winter wheat. European Journal of Agronomy 24: 357-366.

Nightingale, M. J., Marchylo, B. A. , Clear, R. M., Dexter, J. E. \& Preston, K. R. 1999. Fusarium head blight: Effect of fungal proteases on wheat storage proteins. Cereal Chemistry 76: 150-158.

Papoušková, L., Capouchová, I., Kostelanská, M., Škeříková, A., Prokinová, E., Hajšlová, J., Salava, J. \& Faměra, O. 2011. Changes in baking quality of winter wheat with different intensity of Fusarium spp. contamination detected by means of new rheological system Mixolab. Czech Journal of Food Sciences 29: 420-429.

Placinta, C. M., D'Mello, J. P. F. \& Macdonald, A. M. C. 1999. A review of worldwide contamination of cereal grains and animal feed with Fusarium mycotoxins. Animal Feed Science and Technology 78: 21-37.

Polišenská, I. 2011. Fusarium mycotoxins in cereals harvested in 2010. Obilninářské listy 1: 9-12.

Prange, A., Modrow, H., Hormes, J., Kramer, J. \& Kohler, P. 2005. Influence of mycotoxin producing fungi (Fusarium, Aspergillus, Penicillium) on gluten proteins during suboptimal storage of wheat after harvest and competitive interactions between field and storage fungi. Journal of Agricultural and Food Chemistry 53: 6930-6938.

Schollenberger, M., Müller, H. M., Rüfle, M., Suchy, S., Planck, S., \& Drochner, W. 2005. Survey of Fusarium toxins in foodstuffs of plant origin marketed in Germany. International Journal of Food Microbiology 97: 317-326.

Schothorst, R. C. \& van Egmond, H. P. 2004. Report from SCOOP task 3.2.10 „Collection of occurrence data of Fusarium toxins in food and assessment of dietary intake by the population of EU member states". Subtask: trichothecenes. Toxicol Letter 153: 133-143.

Siuda, R., Grabowski, A., Lenc, L., Ralcewicz, M. \& Spychaj-Fabisiak, E. 2010. Influence of the degree of fusariosis on technological traits of wheat grain. International Journal of Food Science \& Technology 45: 2596-2604.

Slovak technical standards 46 1100-2. 2003. Cereals for human consumption. Part 2: Grain of wheat for human consumption. Slovak Office of Standards, Metrology and Testing, SK. 8 p.

Stepień. Ł., Popiel, D., Koczyk, G. \& Chełkowski, J. 2008. Wheat-infecting Fusarium species in Poland--their chemotypes and frequencies revealed by PCR assay. Journal of Applied Genetics 49: 433-441.

Streit, E., Schatzmayr, G., Tassis, P., Tzika, E., Marin, D., Taranu, I., Tabuc, C., Nicolau, A., Aprodu, I., Puel, O. \& Oswald, I. P. 2012. Current Situation of Mycotoxin Contamination and Co-occurrence in Animal Feed-Focus on Europe. Toxins 4: 788-809.

Streit, E., Schwab, C., Sulyok, M., Naehrer, K., Krska, R. \& Schatzmayr, G. 2013. Multi-Mycotoxin Screening Reveals the Occurrence of 139 Different Secondary Metabolites in Feed and Feed Ingredients. Toxins 5: 504-523.

Šliková, S., Šudyová, V. \& Gregová, E. 2008. Deoxynivalenol in wheat from the growing areas of Slovakia. Cereal research communications 36: 279-287.

Šliková, S., Šudyová, V., Martinek, P., Polišenská, I., Gregová, E. \& Mihálik, D. 2009. Assessment of infection in wheat by Fusarium protein equivalent levels. European Journal of Plant Pathology 124: 163-170.

Talas, F., Parzies H. K. \& Miedaner, T. 2011. Diversity in genetic structure and chemotype composition of Fusarium graminearum sensu stricto populations causing wheat head blight in individual fields in Germany. European Journal of Plant Pathology 131: 39-48.

Van der Fels-Klerx, H. J., Olesen, J. E., Madsen, M. S. \& Goedhart, P. W. 2012. Climate change increases deoxynivalenol contamination of wheat in north-western Europe. Food Additives and Contaminants - Part A Chemistry, Analysis, Control, Exposure and Risk Assessment 29: 1593-1604.

Wang, J., Wieser, H., Pawelzik, E., Weinert, J., Keutgen, A. J., Gerhard, A. \& Wolf, G. A. 2005. Impact of the fungal protease produced by Fusarium culmorum on the protein quality and breadmaking properties of winter wheat. European Food Research and Technology 220: 552-559.

Wegulo, S. N. 2012. Factors influencing deoxynivalenol accumulation in small grain cereals. Toxins 4: 1157-1180.

Wiśniewska, H., Łukasz Stępień, L., Waśkiewicz, A., Beszterda, M., Góral, T. \& Belter, J. 2014. Toxigenic Fusarium species infecting wheat heads in Poland. Central European Journal of Biology 9: 163-172.

Yli-Mattila, T. 2010. Ecology and Evolution of toxigenic fusarium species in cereals In Northern Europe and Asia. Journal of Plant Pathology 92: 7-18. 